Leadership: Jurnal mahasiswa manajemen Pendidikan Islam

ISSN (P): 2721-7108, ISSN (E): 2715-0399

DOI : http://dx.doi.org/10.32478/leadership. v3i1.880

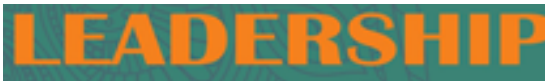

Article Type : Original Research Article

\title{
Perbandingan Manajemen Kurikulum Sebelum Dan Selama Pandemi Covid-19 Di Sekolah Dasar Islam Mohammad Hatta
}

\section{Nur Maulidiyah}

STAI Ma'had Aly Al-Hikam Malang, Indonesia

Corresponding author: Email: nurmaulidiyah@gmail.com

Submission Track:

Submisson

: 04-01-2022

Accept Submission : 04-01-2022

Avaliable Online : :04-01-2022

Copyright @ 2022 Author

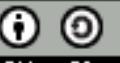

This work is licensed under a Creative Commons Attribution-ShareAlike 4.0

\section{Abstract}

The curriculum is the core subject of education. Oliva mentioned "curriculum that is thought" (what), in the form of programs, plans, materials to be taught (content). Meanwhile, the meaning of learning (instruction) is more of "means used to teach that which is thought" (how), in the form of methods, teaching strategies, teaching approaches, implementation of learning in class and outside the classroom. Once the importance of curriculum management as the main management substance in schools, the basic principles of curriculum management emphasize that the learning process can run well, by measuring the achievement of goals by students and encouraging teachers to develop and continuously perfect learning strategies carried out in class.

The curriculum plays an important role in realizing quality and quality schools, to create a quality curriculum, empowerment in curriculum management is needed. Management of the institutional-level curriculum needs to be coordinated by the leadership which is developed integrally in the context of School-Based Management and the Education Unit Level Curriculum and is adjusted to the vision and mission of the Educational Institution. The SDI Mohammad Hatta curriculum is intended for all school members, especially students, educators and education personnel, the formation of school culture 
can be carried out by schools through a series of planning activities, implementation of learning that is more student-oriented, comprehensive assessment of school-level planning in essence is strengthening the preparation at SDI Mohammad Hatta level, such as establishing a vision, mission, goals, curriculum structure, academy calendar and syllabus preparation. This type of qualitative research uses descriptive research methods. The purpose of this study was to describe the curriculum management at SDI Mohammad Hatta and to describe how the education unit level curriculum was before and during the Covid-19 pandemic.

Keywords: Curriculum Management, Comparison.

\begin{abstract}
Abstrak
Kurikulum adalah inti pendidikan. Oliva menyebut "curriculum that which is thought" (what), berupa program, rencana (plan), materi yang akan diajarkan (content). Sedangkan makna pembelajaran lebih merupakan "means used to teach that which is thought" berupa metode, strategi pengajaran, pendekatan pengajar, implementasi pembelajaran di kelas dan luar kelas. Begitu pentingnya manajemen kurikulum sebagai substansi manajemen yang utama di sekolah, prinsip dasar manajemen kurikulum ini menegaskan agar proses pembelajaran dapat berjalan dengan baik, tolak ukur pencapaian tujuan oleh siswa dan mendorong guru untuk menyusun serta terus menerus menyempurnakan strategi pembelajaran yang dilakukan di kelas.
\end{abstract}

kurikulum memegang peranan penting dalam mewujudkan sekolah bermutu dan berkualitas, untuk membuat kurikulum yang bermutu diperlukan pemberdayaan pada pengelolaan kurikulum. Pengolalaan kurikulum tingkat lembaga perlu di koordinasi oleh pihak pimpinan yang dikembangkan secara integral dalam konteks Manajemen Berbasis Sekolah dan Kurikulum Tingkat Satuan Pendidikan serta disesuaikan dengan visi dan misi Lembaga Pendidikan tersebut. Kurikulum SDI Mohammad Hatta ini diperuntukan kepada semua warga sekolah, terutama peserta didik, pendidik dan tenaga kependidikan, pembentukan budaya sekolah dapat dilakukan oleh sekolah melalui serangkaian kegiatan perencanaan, pelaksanaan pembelajaran yang lebih berorientasi pada peserta didik, penilaian bersifat komprehensif perencanaan tingkat sekolah pada intinya adalah melakukan penguatan dalam penyusunan di tingkat SDI Mohammad Hatta, seperti menetapkan Visi, Misi, tujuan, Struktur kurikulum, Kalender akademi dan penyusunan silabus. Jenis penelitian kualitatif dengan menggunakan metode penelitian deskriptif. Tujuan penelitian ini untuk mendeskripsikan manajemen kurikulum di SDI Mohammad Hatta dan Mendeskripsikan Bagaimana Kurikulum Tingkat Satuan Pendidikan Sebelum dan Selama Pandemi Covid - 19.

Kata Kunci : Manajemem Kurikulum, Perbandingan. 
Leadership: Jurnal mahasiswa manajemen pendidikan Islam

ISSN (P): 2721-7108, ISSN (E): 2715-0399

Vol. 03 No. 01 bulan Desember 2021

\section{PENDAHULUAN}

Pandemi Covid - 19 merupakan musibah yang memilukan seluruh penduduk bumi. Seluruh segmen kehidupan manusia di bumi terganggu, tanpa kecuali pendidikan. Banyak negara memutuskan menutup sekolah, perguruan tinggi maupun universitas, termasuk Indonesia. Krisis benar-benar datang tiba-tiba, pemerintah di belahan bumi manapun termasuk Indonesia harus mengambil keputusan yang pahit menutup sekolah untuk mengurangi kontak orang-orang secara masif dan untuk menyelamatkan hidup atau tetap harus membuka sekolah dalam rangka survive para pekerja dalam menjaga keberlangsungan ekonomi. Ada dua dampak bagi keberlangsungan pendidikan yang disebabkan oleh pandemi Covid-19. Pertama adalah dampak jangka pendek, yang dirasakan oleh banyak keluarga di Indonesia baik di kota maupun di desa. di Indonesia banyak keluarga yang kurang familier melakukan sekolah di rumah. Bersekolah di rumah bagi keluarga Indonesia adalah kejutan besar khususnya bagi produktivitas orang tua yang biasanya sibuk dengan pekerjaannya di luar rumah. Demikian juga dengan problem psikologis anak-anak peserta didik yang terbiasa belajar bertatap muka langsung dengan guru-guru mereka. Seluruh elemen pendidikan secara kehidupan sosial terpapar sakit karena covid-19. Pelaksanaan pengajaran berlangsung dengan cara online. Proses ini berjalan pada skala yang belum pernah terukur dan teruji sebab belum pernah terjadi sebelumnya. Penilaian siswa bergerak online dan banyak trial and error dengan sistem yang tidak ada kepastian, malah banyak penilaian yang banyak dibatalkan. Kedua adalah dampak jangka panjang. Banyak kelompok masyarakat di Indonesia yang akan terpapar dampak jangka panjang dari covid-19 ini. Dampak pendidikan dari sisi waktu jangka panjang adalah aspek keadilan dan peningkatan ketidaksetaraan antar kelompok masyarakat dan antar daerah di Indonesia.

Pada lembaga pendidikan pembentukan sumber daya manusia yang berkualitas adalah tujuan utamanya, Oleh karena itu dalam perekrutannya terdapat tahapan-tahapan tertentu. Dengan adanya tahapan tersebut akan mempermudah lembaga dalam menjaring sumber daya manusia yang memiliki potensi. Sumber daya manusia (SDM) semula merupakan terjemahan dari "human resources". Namun ada pula ahli yang menyamarkan SDM dengan "manpower" (tenaga kerja). Bahkan sebagian orang menyetarakan pengertian SDM dengan "personel" (personalia, kepegawaian, dan sebagainya). Dari pendapat tersebut yang dapat saya pahami mengenai sumber daya manusia adalah seorang pekerja atau tenaga kerja dalam suatu organisasi atau lembaga.

Manajemen sumber daya manusia menurut Henry Simamora adalah pendayagunaan, pengembangan penilaian, pemberian balas jasa, dan pengelolaan individu anggota organisasi atau kelompok karyawan. Manajemen sumber daya manusia merupakan aktivitas-aktivitas yang dilaksanakan agar sumber daya manusia di dalam organisasi dapat digunakan secara efektif guna mencapai berbagai tujuan.

Manajemen sumber daya manusia merupakan serangkaian kegiatan manajemen mulai dari perencanaan, pengorganisasian, pelaksanaan dan pengawasan pekerja untuk mencapai tujuan organisasi. Untuk mendapatkan sumber daya manusia yang sesuai dengan ketentuan yang diinginkan lembaga, maka harus melalui langkah-langkah yang telah dijelaskan dalam manajemen sumber daya manusia, yang mengacu pada visi misi dan tujuan lembaga. Dalam penelitian ini saya lebih banyak membahas mengenai proses seleksi dari beberapa langkah yang harus dilakukan. Sumber daya manusialah yang berperan dalam 
pelaksanaan kurikulum yang diwujudkan melalui proses belajar mengajar untuk mencapai tujuan pendidikan Nasional, institusional, kurikuler dan instruksional. Kurikulum yang merupakan suatu rencana pendidikan, memberikan pedoman dan pegangan tentang jenis, lingkup dan urutan isi, serta proses pendidikan.

Pada pengembangan Kurikulum SDI Mohammad Hatta Kota Malang mengacu pada Standar Nasional Pendidikan untuk menjamin pencapaian tujuan pendidikan nasional. berdasarkan evaluasi diri sekolah tahun pelajaran 2014 / 2015 masih ada yang belum mencapai target yang ingin dicapai terutama Standar Isi, Standar Pembiayaan, Standar Pendidik dan Tenaga Kependidikan, Standar Proses, Standar Pengelolaan ,Standar Penilaian dan Standar Sarana Prasarana. Kurikulum SDI Mohammad Hatta Kota Malang ini disusun agar dapat digunakan sebagai acuan sekolah dalam penyusunan dan pengembangan program pendidikan yang akan dilaksanakan, agar sesuai dengan karakteristik, potensi, dan kebutuhan peserta didik. Oleh karena itu, dalam pengembangan kurikulum ini, SDI Mohammad Hatta Kota Malang melibatkan seluruh warga sekolah dan berkoordinasi dengan pemangku kepentingan (stake holders).

Manajemen Kurikulum merupakan sebuah bentuk usaha atau upaya bersama untuk memperlancar pencapaian tujuan pengajaran. Pada manajemen kurikulum itu mengatur kebutuhan pendidikan. Pelaksanaan kurikulum menghasilkan perubahanp - perubahan yang strategis sebagai dampak implementasi kurikulum yang akhirnya evaluasi dan pengendalian mutu mulai dari perencanaan, pelaksanaan, maupun tindak lanjut kurikulum menghasilkan outcome yang dapat diukur secara kuantitas dan kualitas. Lulusan pendidikan ini diharapkan menjadi individu yang produktif, mandiri, dan profesional yang mampu bekerja menjadi tenaga kerja menengah dan memiliki kesiapan untuk menghadapi persaingan kerja sesuai dengan bidang keahliannya. manajemen kurikulum salah satu aspek yang berpengaruh terhadap keberhasilan pembelajaran pada lembaga pendidikan nasional. kurikulum memegang peranan penting dalam mewujudkan sekolah yang bermutu dan berkualitas, untuk membuat kurikulum yang bermutu diperlukan pemberdayaan pada pengelolaan kurikulum. pengolalaan kurikulum pada tingkat Lembaga perlu di koordinasi oleh pihak pimpinan yang dikembangkan secara integral dalam konteks manajemen berbasis sekolah (MBS) dan kurikulum tingkat satuan Pendidikan (KTSP) serta disesuaikan dengan visi dan misi Lembaga Pendidikan tersebut. Tujuan penelitian ini untuk mendeskripsikan manajemen kurikulum di SDI Mohammad Hatta dan Mendeskripsikan Bagaimana Kurikulum K - 13 Sebelum dan Selama Pandemi Covid - 19.

\section{LITERATUR REVIEW}

\section{A. Manajemen Kurikulum}

1. Manajemen

Manajemen berasal dari kata to manage yang berarti mengatur, mengurus, mengelola. ${ }^{1}$ Dalam bahasa indonesia dapat diartikan sebagai mengendalikan, menangani atau mengelola. Secara umum, manajemen adalah pengelolaan suatu

\footnotetext{
${ }^{1}$ Dita Amanah, Pengantar Manajemen (Medan: UNIMED, 2010), hlm 2.
} 
pekerjaan untuk memperoleh hasil dalam rangka pencapaian tujuan yang telah ditentukan dengan cara menggerakkan orang - orang lain bekerja. ${ }^{2}$

Hasibuan menegaskan bahwa manajemen adalah ilmu dan seni mengatur proses pemanfaatan sumber daya manusia secara efektif yang didukung oleh sumber - sumber lainnya dalam suatu organisasi untuk mencapai tujuan tertentu. Manajemen merupakan bagian penting dalam sebuah organisasi, tidak terkecuali dalam manajemen pendidikan, karena manajemen yang menjadi penentu baik tidaknya kualitas pendidikan tersebut, begitu pula dalam sistem pendidikan di Sekolah Dasar Islam Mohammad Hatta.

Penggunaan ilmu manajemen pada proses pemerataan pendidikan dalam lingkup sebuah lembaga pendidikan memiliki peranan dan kedudukan yang sangat penting dan merupakan salah satu dari bagian yang diharuskan ada pada setiap pemberlakuan kebijakkan yang telah diputuskan oleh sebuah lembaga pendidikan. Penggunaan ilmu manajemen dalam hal ini memiliki peranan sebagai dasar yang akan menjadi pengarah dan pembatas dari suatu kebijakkan yang telah dibentuk, agar tujuan dari pembentukan suatu kebijakkan tersebut dapat terwujudkan dengan maksimal.

Pada sebuah lembaga pendidikan, mengandung berbagai komponen yang antara satu dengan yang lainnya saling berkaitan. Komponen pendidikan tersebut terdiri dari landasan, tujuan, kurikulum, kompetensi, profesionalisme guru, pola hubungan guru dengan murid, metodologi pembelajaran (ilmu tentang metode pembelajaran), sarana dan prasarana, evaluasi, pembiayaan, dan lain sebagainya. ${ }^{3}$ Penelitian ini akan membahas bagaimana manajemen yang dilakukan lembaga pendidikan tersebut dalam meningkatkan ketaatan beribadah siswanya. Sistem lembaga pendidikan formal tidak terlepas dari manajemen dalam menjalankan fungsinya untuk mencapai visi, misi dan tujuan. madrasah seharusnya mempunyai manajemen yang baik mulai dari perencanaan, pelaksanaan serta evaluasinya. Manajemen dapat berjalan dengan baik pada sebuah lembaga pendidikan apabila ada kerjasama antara guru, serta lingkungan sekolah dan masyarakat.

2. Kurikulum

Curriculum dalam bahasa Yunani kuno berasal dari kata curir yang artinya pelari atau curere yang artinya tempat berpacu. Curriculum diartikan jarak yang harus ditempuh oleh pelari. Berdasarkan kalimat ini kurikulum pendidikan diartikan sebagai sejumlah mata pelajaran yang harus ditempuh atau diselesaikan anak didik untuk memperoleh ijazah. ${ }^{4}$

Kurikulum adalah inti pendidikan ( core subject of education ). Oliva menyebut "curriculum that which is thought" (what), berupa program, rencana (plan), materi/bahan yang akan diajarkan (content). Sedangkan makna pembelajaran

\footnotetext{
${ }^{2}$ Yayat M. Herujito, Dasar - Dasar Manajemen, (Jakarta: PT Grasindo, 2006), hlm. 2

${ }^{3}$ Abuddin Nata, Manajemen Pendidikan, (Jakarta: Prenada Media, 2003), hlm. 1 - 2.

${ }^{4}$ Sri Minarti, Manajemen Sekolah: Mengelola Lembaga Pendidikan Secara Mandiri, (Jogjakarta: Ar-Ruzz Media, 2013), hlm. 89.
} 
(instruction) lebih merupakan "means used to teach that which is thought" (how), berupa metode, strategi pengajaran, pendekatan pengajar, implementasi pembelajaran di kelas dan luar kelas.

Kurikulum pendidikan sangat penting, karena tanpa adanya kurikulum maka pendidikan tidak akan berjalan dengan baik. Kurikulum merupakan program pendidikan (sekolah) bagi peserta didik. Pengelolaan pendidikan yang ada di suatu lembaga merupakan langkah untuk meningkatkan pendidikan yang bermutu, sehingga berbagai macam program dan perencanaan dilakukan untuk mencapai apa yang menjadi visi misi lembaganya. Hal itu menjadi tugas utama bagi pihak lembaga, apalagi pengelola lembaga atau kepala sekolah yang memiliki peran penting dalam kemajuan lembaganya. Untuk meningkatkan mutu pendidikan salah satu komponen manajemen pendidikan yang harus diperhatikan oleh kepala sekolah adalah manajemen kurikulum. Manajemen kurikulum sebagai salah satu substansi atau standar manajemen pendidikan memperlihatkan bahwa perlu adanya keterkaitan kuat di setiap bagiannya. Salah satu aspek dalam manajemen pendidikan yang sering disebut sebagai jantungnya pendidikan adalah kurikulum.

Kurikulum dikembangkan dengan memperhatikan kepentingan nasional dan kepentingan daerah untuk membangun kehidupan bermayarakat, berbangsa dan bernegara. Kepentingan nasional dikembangkan melalui penentuan struktur kurikulum, Standar kemampuan (SK) dan Kemampuan dasar (KD) serta silabus. Kepentingan daerah dikembangkan untuk membangun manusia yang bermartabat dan mampu berkonstribusi secara langsung kepada masyarakat sekitarnya. Kedua kepentingan ini saling mengisi dan memberdayakan keragaman dan kebersatuan dalam kerangka Bhinneka Tunggal lka.

Begitu pentingnya manajemen kurikulum sebagai substansi manajemen yang utama di sekolah, prinsip dasar manajemen kurikulum ini menegaskan agar proses pembelajaran dapat berjalan dengan baik, dengan tolak ukur pencapaian tujuan oleh siswa dan mendorong guru untuk menyusun dan terus menerus menyempurnakan strategi pembelajaran yang dilakukan di kelas. ${ }^{5}$ Manajemen kurikulum disekolah meliputi kegiatan perencanaan (planning), pelaksanaan (action) dan evaluasi (evaluating) yang bertujuan agar seluruh kegiatan pembelajaran terlaksana secara berhasil. ${ }^{6}$

\section{a. Perencanaan}

Menurut Beane : 1996, "Curriculum planning is a process in which paticipants at many levels make decicions about what the purposes of learning ought to be, how those purposes might be carried out though teaching - learning situations, and whether the purposes and mean are both appropriate and effective."

Cunningham mengemukan bahwa perencanaan adalah menyeleksi dan menghubungkan pengetahuan,fakta,memvisualisasi dan memformulasi hasil yang diinginkan, urutan kegiatan yang diperlukan, dan perilaku dalam batas-batas yang

\footnotetext{
${ }^{5}$ Nita, Manajemen Kurikulum, ( Bandung : Perdana Publishing 2014 ), hlm. 5

${ }^{6}$ Sri Minarti, Manajemen Sekolah: Mengelola Lembaga Pendidikan Secara Mandiri, (Jogjakarta: Ar-Ruzz Media, 2013), hlm. 91.
} 
dapat diterima yang akan digunakan dalam penyelesaian. Perencanaan disini menekankan pada usaha menyeleksi dan menghubungkan sesuatu dengan kepentingan masa yang akan datang serta usaha untuk mencapainya. Apa wujud yang akan datang itu dan bagaimana usaha untuk mencapainya merupakan perencanaan. ${ }^{7}$

Pada pengertian tersebut perencanaan kurikulum adalah suatu proses ketika peserta dalam banyak tingkatan membuat keputusan tentang tujuan belajar, cara mencapai tujuan tersebut melalui situasi mengajar-belajar, serta memperkirakan kebermaknaan dan penelaahan keefektifan metode tersebut. ${ }^{8}$

Pada perencanaan kurikulum, hubungan antara tujuan dan alat atau metode pencapai tujuan tersebut harus direncanakan agar dapat berjalan selaras agar dapat terbentuk sebuah kurikulum yang baik dan dapat menghasilkan peserta didik yang berkualitas. Hubungan antara tujuan dan alat atau metode yang diharuskan dapat berjalan berdampingan dengan baik, membuat dalam perencanaan kurikulum memerlukan kemampuan manajemen agar dapat merencanakan dan mengorganisasikan perencanaan kurikulum tersebut secara profesional.

Perencanaan kurikulum harus dibuat dalam kerangka kerja yang komprehensif, yang mempertimbangkan dan mengodinasi unsur esensial belajar mengajar efektif. Perencanaan kurikulum harus bersifat reaktif dan antisipasif. Pendidikan harus responsif terhadap kebutuhan individu siswa, untuk membantu siswa tersebut menuju kehidupan yang kondusif.

\section{b. Pelaksanaan}

Implementasi merupakan suatu proses penerapan ide, konsep,kebijakan, atau inovasi dalam suatu tindakan praktis sehingga memberikan dampak baik berupa perubahan pengetahuan, keterampilan, nilai, dan sikap. Oxford Advance Learner's Dictionary dikemukakan bahwa implementasi adalah "put something info effect" (penerapan sesuatu yang memberikan efek atau dampak).

Berdasarkan definisi implementasi tersebut, implementasi kurikulum tingkat satuan pendidikan dapat didefinisikan sebagai suatu proses penerapan ide, konsep, dan kebijakan kurikulum (kurikulum potensial) dalam suatu aktivitas pembelajaran sehingga peserta didik menguasai seperangkat kompetensi tertentu sehingga hasil interaksi dalam lingkungan.

Implementasi kurikulum juga dapat diartikan sebagai aktualisasi kurikulum tertulis dalam bentuk pembelajaran. Hal tersebut sejalan dengan apa yang diungkapkan Miller dan Seller bahwa implementasi kurikulum merupakan suatu proses penerapan konsep, ide, program, atau tataran kurikulum ke dalam praktek pembelajaran atau aktivitas-aktivitas baru sehingga terjadi perubahan pada sekelompok orang yang diharapkan untuk berubah. Menurut penulis implementasi kurikulum adalah proses perubahan untuk memperoleh hasil yang mendekati pencapaiaujuan pendidikan yang ideal.

\footnotetext{
${ }^{7}$ Willian, G Cunningham, Systematic Planning for Educational Change, First Edition, Mayfield Publishing Company, California,1982, hlm. 4.

${ }^{8}$ Oemar Hamalik, Dasar-Dasar Pengembangan Kurikulum, (Cet. V ; Bandung : PT Remaja Rosdakarya, 2013), hlm. 171.
} 


\section{c. Evaluasi Kurikulum}

Pada kurikulum terdapat evaluasi sebagai tolak ukur perubahan kajian yang telah disediakan. Latar belakang pendidikan evaluator adalah merupakan faktor lain yang menyebabkan terjadinya perbedaan dalam definisi evaluasi kelompok kurikulum yang digunakan. ${ }^{9}$ Evaluasi adalah suatu kegiatan atau proses yang sistematis, berkelanjutan, dan menyeluruh dalam rangka pengendalian, penjaminan, dan penetapan kualitas berbagai komponen pembelajaran berdasarkan pertimbangan dan kriteria tertentu.

Evaluasi bertujuan untuk menentukan atau membuat keputusan sampai sejauh mana tujuan-tujuan pengajaran telah dicapai. Evaluasi juga ditujukan untuk menganalisis tingkat efisiensi pelaksanaan program. Dengan demikian, evaluasi berhubungan dengan keputusan nilai, yang berkaitan dengan keseluruhan program.

Menurut Tayler evaluasi kurikulum adalah prosesuntuk menetukan sejauh mana perubahan perilaku ini benar-benar terjadi. Jadi, Evaluasi Kurikulum adalah proses mengumpulkan informasi tentang pembelajaran dengan tujuan membuat penilaian yang diinformasikan dan untuk pengambilan keputusan. ${ }^{10}$ Evaluasi kurikulum dimaksudkan untuk memeriksa kinerja kurikulum secara keseluruhan ditinjau dari beberapa aspek yaitu efektifitas, relevansi, efisiensi dan kelayakan (feasibility) program. ${ }^{11}$

Pada kurikulum 2013, ada tiga fokus pengembangan kurikulum, yaitu standar kompetensi lulusan, standar proses, dan standar penilaian. Dalam kemendikbud No.66 tahun 2013, dideskripsikan adanya empat elemen perubahan dalam standar penilaian pendidikan, yaitu:

1) Penilaian berbasis kompetensi

2) Pergeseran dari penilaian melalui tes menuju penilaian autentik

3) Penilaian tidak hanya pada level kompetensi dasar, tetapi juga kompetensi inti dan standar kelulusan

4) Mendorong pemanfaatan portofolio yang dibuat siswa sebagai instrumen utama penilaian dan penilaian mandiri oleh siswa

\section{B. Kurikulum Tingkat Satuan Pendidikan}

KTSP lebih mengutamakan untuk merealisasikan dan merelevasikan antara kurikulum nasional (standar kompetensi / kompetensi dasar) dengan kebutuhan daerah dan kondisi sekolah yang bersangkutan, sehingga kurikulum tersebut merupakan kurikulum tersebut merupakan kurikulum yang integritas dengan peserta didik maupun lingkungan dimana sekolah itu berada. Apapun dan bagaimanapun kurikulumnya yang

\footnotetext{
${ }^{9}$ S. Hamid Hasan, Evaluasi Kurikulum, (Cet. II; Bandung : PT Remaja Rosda Karya, 2009) hlm. 35.

${ }^{10}$ Hanun Asrohah, Pengembangan Kurikulum, (Cet. VII : Surabaya : Kompertais IV Press, 2015) hlm, 334

${ }^{11}$ ibid... hlm. 42-43.
} 
paling penting dilakukan oleh guru adalah menjabarkanya kedalam Rencana Pelaksanaan Pembelajaran (RPP).

Pada kegiatan belajar, siswa tidak hanya berinteraksi dengan guru sebagai salah satu sumber belajar, tetapi mungkin berinteraksi dengan keseluruhan sumber belajar yang dipakai untuk mencapai tujuan pembelajaran yang diinginkan. Adapun mengenai apa isi pembelajaran yang harus dipelajari siswa agar dapat tercapainya tujuan pembelajaran adalah perhatian bidang kajian dari kurikulum.

Pembelajaran yang akan direncanakan memerlukan berbagai teori untuk merancangnya agar rencana pembelajaran yang disusun benar benar dapat memenuhi harapan dan tujuan pembelajaran. Untuk itu sebagaimana pembelajaran yang disebut oleh Reigeluth adalah sebagai suatu disiplin ilmu yang menaruh perhatian pada perbaikan kualitas pembelajaran dengan menggunakan teori pembelajaran deskriptif, sedangkan rancangan pembelajaran mendekati tujuan yang sama dengan berpijak pada teori pembelajaran preskriptif. ${ }^{12}$

\section{Kurikulum K - 13}

Covid-19 telah menjadi pandemi dunia saat ini, tidak terkecuali Indonesia. Hal ini menyebabkan pemerintah di berbagai belahan dunia menerapkan sejumlah kebijakan baru terkait untuk memutus mata rantai penularan virus tersebut, pun dengan pemerintah Indonesia. Pemerintah Indonesia melalaui PP No. 21 Tahun 2020 menerbitkan kebijakan pembatasan sosial berskala besar (social distancing) terkait aktivitas kerja, dunia usaha, perkantoran, pendidikan, keagamaan, ekonomi atau pun aktivitas sosial lainnya. Begitu juga dengan Kabupaten Demak, dalam Peraturan Bupati Demak No. 45 Tahun 2020 disebutkan kebijakan tentang pembatasan sosial berskala besar (social distancing) termasuk di dalamnya dunia pendidikan. Hampir semua lini terdampak dengan adanya pandemi Covid-19 ini, termasuk juga pendidikan. Khusus dunia pendidikan, pemerintah mengubah moda pembelajaran di sekolah maupun perguruan tinggi sejak 16 Maret 2020 sampai waktu yang akan diberitahukan lebih lanjut. Dalam Surat Edaran Mendikbud Nomor 4 Tahun 2020, salah satunya menyebutkan bahwa sekolah di seluruh Indonesia dianjurkan belajar di rumah untuk beberapa waktu sampai ada pemberitahuan lebih lanjut.

Pandemi ini telah memaksa sistem pembelajaran di sekolah berubah secara drastis dari pembelajaran tatap muka (konvensional) menjadi pembelajaran secara online/daring. Banyak pihak yang merasa belum siap untuk implementasi pembelajaran online, baik dari guru, siswa, maupun orang tua. Apalagi jika harus menerapkan kurikulum 2013 yang begitu kompleks dalam sebuah pembelajaran online. Hal ini tentunya akan memengaruhi baik perencanaan, proses, maupun hasil pembelajaran.

Pada penerapan kurikulum 2013, seorang guru hendaknya paham bahwa setiap mata pelajaran harus mencakup 3 kompetensi, yaitu sikap, pengetahuan, dan keterampilan. Semuanya itu diajarkan dengan pendekatan saintifik secara terpadu. Hal ini akan mudah jika pembelajaran dilaksanakan secara tatap muka. Berbeda jika dilaksanakan secara online. Hambatan lainnya adalah masih ditemukan guru yang belum melek teknologi untuk menerapkan kurikulum 2013 dalam pembelajaran online. Belum lagi, kurangnya

12 E. Mulyasa, Implementasi Kurikulum Tingkat Satuan Pendidikan Kemandirian Guru dan kepala Sekolah, (Jakarta : Bumi Aksara, 2009), hlm 156 
infrastruktur pendukung pembelajaran online itu sendiri. Untuk melihat seberapa tinggi keefektifan implementasi kurikulum 2013 dalam pembelajaran online selama masa pandemi Covid-19 ini, perlu adanya suatu evaluasi terhadap implementasi pembelajaran tersebut.

Kurikulum 2013 memiliki tujuan khusus untuk mempersiapkan generasi baru dan penerus bangsa yang memiliki kemampuan hidup sebagai pribadi dan warga negara yang beriman, produktif, kreatif, inovatif, dan afektif serta mampu berkontribusi pada kehidupan bermasyarakat, berbangsa, bernegara, dan peradaban dunia. Untuk itu, perancangan kurikulum 2013 perlu memperhatikan kebutuhan siswa saat ini dan di masa depan yang dinamis ditengah pengaruh globalisasi dan kemajemukan masyarakat Indonesia.

\section{METODE PENELITIAN}

Tujuan penelitian ini adalah untuk mengetahui manajemen kurikulum yang ada di SDI Mohammad Hatta. Penelitian ini merupakan jenis penelitian kualitatif dengan menggunakan metode penelitian deskriptif. Menurut Jasa Ungguh, metode penelitian deskriptif adalah metode penelitian yang berisi pemaparan atau penggambaran sesuatu, metode deskriptif secara umum berisi uraian-uraian dan penjelasan mengenai objek yang diteliti. ${ }^{13}$

Pada penelitian ini pendekatan yang dilakukan adalah melalui pendekatan kualitatif. Artinya data yang dikumpulkan bukan berupa angka-angka, melainkan data, dimana data-data tersebut berasal dari naskah wawancara, catatan lapangan, dokumen pribadi, dan dokumen resmi lainnya. Sehingga yang menjadi tujuan dari penelitian kualitatif adalah menggambarkan realita di balik fenomena secara mendalam, rinci dan tuntas. Sesuai dengan fokus penelitian tentang manajemen kurikulum.

Menurut Kirk dan Miller dalam Lexy J. Moleong mendefinisikan bahwa penelitian kualitatif adalah tradisi tertentu dalam ilmu pengetahuan sosial yang secara fundamental bergantung pada pengamatan terhadap manusia dalam kawasannya sendiri dan berhubungan dengan orang-orang tersebut dalam bahasanya dan dalam peristilahannya. ${ }^{14}$ Suharsimi Arikunto mengungkapkan bahwa penelitian kualitatif adalah sebagai prosedur penelitian yang menghasilkan data deskriptif berupa kata-kata, tulisan atau lisan dari perilaku orang-orang yang diamati. ${ }^{15}$

\section{HASIL}

\section{A. Manajemen Kurikulum}

Kurikulum yang dipakai kurikulum dari dinas, kurikulum khas SDI Mohammad Hatta, seperti komputer bahasa arab dan bahasa inggris, hidden kurikulum (Budaya Islami, Al Qur'an). Perencanaan kurikulum harus dibuat dalam kerangka kerja yang komprehensif,

\footnotetext{
${ }^{13}$ Jasa Ungguh M, Metodologi Penelitian Pendidikan, (Yogyakarta: Gava Media, 2014), hlm. 84

${ }^{14}$ Lexi J Moloeng, Metodologi Penelitian Kualitatif, (Bandung : Remaja Rosdakarya, 2006), hlm 6

${ }^{15}$ Suharsimi Arikunto, Prosedur Penelitian; Suatu Pendekatan Praktek, (Yogyakarta : PT. Rineka Cipta, 1998), hlm 131
} 
yang mempertimbangkan dan mengodinasi unsur esensial belajar-mengajar efektif. Perencanaan kurikulum harus bersifat reaktif dan antisipasif. Pendidikan harus responsif terhadap kebutuhan individu siswa, untuk membantu siswa tersebut menuju kehidupan yang kondusif.

Struktur kurikulum menggambarkan konseptualisasi konten kurikulum dalam bentuk mata pelajaran, posisi konten/mata pelajaran dalam kurikulum, distribusi mata pelajaran dalam semester atau tahun, beban belajar untuk mata pelajaran dan beban belajar per minggu untuk setiap peserta didik. Struktur kurikulum adalah juga merupakan aplikasi konsep pengorganisasian konten dalam sistem belajar dan pengorganisasian beban belajar dalam sistem pembelajaran. Pengorganisasian konten dalam sistem belajar yang digunakan untuk kurikulum yang akan datang adalah sistem semester sedangkan pengorganisasian beban belajar dalam sistem pembelajaran berdasarkan jam pelajaran per semester.

Struktur kurikulum adalah juga gambaran mengenai penerapan prinsip kurikulum mengenai posisi seorang peserta didik dalam menyelesaikan pembelajaran di suatu satuan atau jenjang pendidikan. Dalam struktur kurikulum menggambarkan ide kurikulum mengenai posisi belajar seorang peserta didik yaitu apakah mereka harus menyelesaikan seluruh mata pelajaran yang tercantum dalam struktur ataukah kurikulum memberi kesempatan kepada peserta didik untuk menentukan berbagai pilihan. Struktur kurikulum terdiri atas sejumlah mata pelajaran yang dicakup dalam beberapa tema, dan beban belajar. Beban belajar dinyatakan dalam jam belajar setiap minggu untuk masa belajar selama satu semester. Beban belajar di SD Tahun I, II, dan III masing-masing 30, 32, 34, sedangkan untuk Tahun IV, V, dan VI masing-masing 36 jam setiap minggu. Jam belajar SD adalah 35 menit.

Manajemen Kurikulum di SDI Mohammad Hatta terdapat berbagai macam perencanaan pelaksanaan dan evaluasi. Perencanaan kurikulum di SDI Mohammad Hatta setiap tahunnya selalu ada rapat untuk membuat (KTSP) Kurikulum Tingkat Satuan Pendidikan yang biasa disebut dengan :

1. Dokumen Satu

Pada bagian dokumen satu berisi tentang Latar Belakang, Visi, Misi, Tujuan Pendidikan, Tujuan setiap mata pelajaran, dan Tujuan Sekolah.

2. Dokumen Dua

Pada Dokumen dua berisi tentang Silabus, RPP, dan Administrasi Pembelajaran yang masuk dalam Kurikulum, yaitu :
a. Adanya Silabus
b. Analisis KI / KD
c. Menyusun PBM / KKM Kompetensi Ketuntasan Minimal
d. RPP
e. Prota Promes
f. Menyusun Hari Efektif Belajar
g. Menyusun Penjadwalan Studi Kurikulum
h. Kalender Pendidikan 
Leadership: Jurnal mahasiswa manajemen pendidikan Islam

ISSN (P): 2721-7108, ISSN (E): 2715-0399

Vol. 03 No. 01 bulan Desember 2021

Pada penyusunan kurikulum juga ada Tim Penyusun Kurikulum yang ikut partisipasi yaitu:

a. Kepala Sekolah

b. Perwakilan Guru

c. Perwakilan Komite

d. Perwakilan Yayasan

e. Perwakilan Akademisi

f. Pengawas atau Tokoh Masyarakat

jadi, semakin banyak tim penyusunya maka kurikulum itu akan menjadi bagus.

\section{B. Visi, Misi, dan Tujuan SDI Mohammad Hatta}

- Visi SDI Mohammad Hatta

Meletakkan dasar - dasar pengembangan sumber daya insan yang berkualitas di bidang IPTEK dan IMTAQ.

- Misi SDI Mohammad Hatta

Menyelenggarakan pendidikan dasar yang beriorentasi kualitas, baik keilmuan, moral maupun social, berlandasan agama islam.

- Tujuan SDI Mohammad Hatta

Memberikan kemampuan baca tulis, hitung pengetahuan dan keterampilan dasar berkehidupan, kemampuan dasar tentang agama Islam dan pengalamannya sesuai dengan ajaran Islam.

\section{PEMBAHASAN}

\section{A. Kurikulum Tingkat Satuan Pendidikan}

Untuk menyukseskan implementasi KTSP, RPP harus disusun secara sistemtik dan sistematis, utuh dan menyeluruh, dengan beberapa kemungkinan penyesuaian dalam situasi pembelajaran yang aktual. ${ }^{16}$ Pada kegiatan belajar, siswa tidak hanya berinteraksi dengan guru sebagai salah satu sumber belajar, tetapi mungkin berinteraksi dengan keseluruhan sumber belajar yang dipakai untuk mencapai tujuan pembelajaran yang diinginkan. Adapun mengenai apa isi pembelajaran yang harus dipelajari siswa agar dapat tercapainya tujuan pembelajaran adalah perhatian bidang kajian dari kurikulum.

Pembelajaran yang akan direncanakan memerlukan berbagai teori untuk merancangnya agar rencana pembelajaran yang disusun benar benar dapat memenuhi harapan dan tujuan pembelajaran. Untuk itu sebagaimana pembelajaran yang disebut oleh Reigeluth adalah sebagai suatu disiplin ilmu yang menaruh perhatian pada perbaikan kualitas pembelajaran dengan menggunakan teori pembelajaran deskriptif,

${ }^{16}$ E. Mulyasa, Implementasi Kurikulum Tingkat Satuan Pendidikan Kemandirian Guru dan kepala Sekolah, (Jakarta : Bumi Aksara, 2009), hlm 156 
Leadership: Jurnal mahasiswa manajemen pendidikan Islam

ISSN (P): 2721-7108, ISSN (E): 2715-0399

Vol. 03 No. 01 bulan Desember 2021

sedangkan rancangan pembelajaran mendekati tujuan yang sama dengan berpijak pada teori pembelajaran preskriptif. ${ }^{17}$

\section{B. Kurikulum $\mathrm{K}-13$}

Muatan Kurikulum SDI Mohammad Hatta mengacu pada Kurikulum 2013 yang dipadukan dengan kurikulum khas meliputi sejumlah mata pelajaran yang terbagi menjadi kelompok A, kelompok B dan kelompok C seperti dalam tabel struktur kurikulum. Dalam muatan Kurikulum 2013 memuat Kompetensi Inti dan Kompetensi Dasar. Kompetensi Inti merupakan terjemahan atau operasionalisasi Standar Kompetensi Lulusan dalam bentuk kualitas yang harus dimiliki oleh peserta didik yang telah menyelesaikan pendidikan pada satuan pendidikan tertentu atau jenjang pendidikan tertentu, gambaran mengenai kompetensi utama yang dikelompokkan ke dalam aspek sikap, keterampilan, dan pengetahuan yang harus dipelajari peserta didik untuk suatu jenjang sekolah, kelas dan mata pelajaran. Kompetensi Inti harus menggambarkan kualitas yang seimbang antara pencapaian hard skills dan soft skills.

Kompetensi Inti berfungsi sebagai unsur pengorganisasi (organising element) kompetensi dasar. Sebagai unsur pengorganisasi, Kompetensi Inti merupakan pengikat untuk organisasi vertikal dan organisasi horizontal Kompetensi Dasar. Organisasi vertikal Kompetensi Dasar adalah keterkaitan antara konten Kompetensi Dasar satu kelas atau jenjang pendidikan ke kelas/jenjang di atasnya sehingga memenuhi prinsip belajar yaitu terjadi suatu akumulasi yang berkesinambungan antara konten yang dipelajari peserta didik. Organisasi horizontal adalah keterkaitan antara konten Kompetensi Dasar satu mata pelajaran dengan konten Kompetensi Dasar dari mata pelajaran yang berbeda dalam satu pertemuan mingguan dan kelas yang sama sehingga terjadi proses saling memperkuat.

Kompetensi Inti dirancang dalam empat kelompok yang saling terkait yaitu berkenaan dengan sikap keagamaan (Kompetensi Inti 1), sikap sosial (Kompetensi Inti 2), pengetahuan (Kompetensi Inti 3), dan penerapan pengetahuan (Kompetensi Inti 4). Keempat kelompok itu menjadi acuan dari Kompetensi Dasar dan harus dikembangkan dalam setiap peristiwa pembelajaran secara integratif. Kompetensi yang berkenaan dengan sikap keagamaan dan sosial dikembangkan secara tidak langsung (indirect teaching) yaitu pada waktu peserta didik belajar tentang pengetahuan (Kompetensi Inti 3) dan penerapan pengetahuan (Kompetensi Inti 4). Kompetensi Inti Dan Kompetensi Dasar Kelas I

1. Pendidikan Agama Islam (terlampir)

2. Pendidikan Pancasila dan Kewarganegaraan

3. Bahasa Indonesia dll

Keberhasilan Kurikulum 2013 dalam membentuk kompetensi dan karakter di sekolah dapat diketahui dari berbagai perilaku sehari - hari terlihat dalam aktivitas peserta didik

17 Merrill, M.D., Component Display Theory, dalam C.M. Reigeluth (Ed.) Instructional Design Theories and Modelas: An Overvieew Of their Current Status. Hillsdale, N.J., Lawrence Erlbaum Associates, 1983, hlm. 279-334 
dan warga sekolah lainnya. Perilaku tersebut antara lain diwujudkan dalam bentuk : kejujuran, kesadaran, kemandirian, kepedulian, dan komitmen.

Kurikulum 2013 memiliki tujuan khusus untuk mempersiapkan generasi baru dan penerus bangsa yang memiliki kemampuan hidup sebagai pribadi dan warga negara yang beriman, produktif, kreatif, inovatif, dan afektif serta mampu berkontribusi pada kehidupan bermasyarakat, berbangsa, bernegara, dan peradaban dunia. Untuk itu, perancangan kurikulum 2013 perlu memperhatikan kebutuhan siswa saat ini dan di masa depan yang dinamis ditengah pengaruh globalisasi dan kemajemukan masyarakat Indonesia.

Pada pengembangan Kurikulum ini, SDI Mohammad Hatta Kota Malang mengacu pada Standar Nasional Pendidikan untuk menjamin pencapaian tujuan pendidikan nasional. Oleh sebab itu perubahan-perubahan yang terjadi dalam kurikulum selalu menjadi prioritas utama untuk selalu disikapi sebagai respon positif bagi sekolah. Seperti halnya dengan arah kebijakan nasional terkait dengan adanya pembangunan pendidikan dan kebudayaan tahun 2015 - 2019 yang merupakan Nawacita yang telah tertuang dalam RPJMN 2015 - 2019 yaitu :

1. Meningkatkan kualitas hidup manusia Indonesia.

2. Melakukan revolusi karakter bangsa.

3. Meningkatkan produktivitas rakyat dan daya saing di pasar internasional.

4. Memperteguh kebhinekaan dan memperkuat restorasi sosial Indonesia.

Arah kebijakan pendidikan dan kebudayaan merupakan dasar juga dalam pembuatan acuan penyusunan kurikulum ini. Begitu juga dengan kebijakan terkait dengan Penguatan Pendidikan Karakter ( PPK ) dengan tujuan sebagai berikut :

1. Mengembangkan platforma pendidikan nasional yang meletakkan makna dan nilai karakter sebagai jiwa atau generator utama penyelenggaraan pendidikan, dengan memperhatikan kondisi keberagaman satuan pendidikan di seluruh wilayah Indonesia.

2. Membangun dan membekali Generasi Emas Indonesia 2045 menghadapi dinamika perubahan di masa depan dengan keterampilan abad 21.

3. Mengembalikan pendidikan karakter sebagai ruh dan fondasi pendidikan melalui harmonisasi olah hati (etik), olah rasa (estetik), olah pikir (literasi), dan olah raga (kinestetik).

4. Merevitalisasi dan memperkuat kapasitas ekosistem pendidikan (kepala sekolah, guru, siswa, pengawas dan komite sekolah) untuk mendukung perluasan implementasi pendidikan karakter.

5. Membangun jejaring pelibatan publik sebagai sumber-sumber belajar di dalam dan di luar sekolah.

6. Melestarikan kebudayaan dan jati diri bangsa Indonesia dalam mendukung Gerakan Nasional Revolusi Mental (GNRM).

Kurikulum SDI Mohammad Hatta Kota Malang ini disusun agar dapat digunakan sebagai acuan sekolah dalam penyusunan dan pengembangan program pendidikan yang akan dilaksanakan, agar sesuai dengan karakteristik, potensi, dan kebutuhan peserta didik. Oleh karena itu, dalam pengembangan kurikulum ini, SDI Mohammad Hatta Kota Malang melibatkan seluruh warga sekolah dan berkoordinasi dengan pemangku kepentingan (stake holders). 
Leadership: Jurnal mahasiswa manajemen pendidikan Islam

ISSN (P): 2721-7108, ISSN (E): 2715-0399

Vol. 03 No. 01 bulan Desember 2021

\section{Kurikulum K - 13 Selama Pandemi Covid -19}

Kondisi masa pandemi covid-19 saat ini memungkinkan untuk pembelajaran dalam jaringan (daring) bagi peserta didik. Kurikulum yang mengacu dan ditetapkan oleh pemerintah yaitu kurikulum nasional dimana kunci keberhasilan implementasinya terletak pada kolaborasi guru, siswa dan orang tua. Untuk mendukung pembelajaran dalam kondisi pandemi covid-19 saat ini lembaga pendidikan menyiapkan bahan ajar melalui aplikasi yang akan digunakan untuk pembelajaran daring tahun ajaran baru. Sebagaimana yang dijelaskan Zubaidah bahwa hampir setiap satuan pendidikan di Kota Malang sudah memanfaatkan E-Learning dalam pelaksanaan pembelajaran. Berdasarkan bahan dari Seamoloc 2020 dipaparkan contoh pola pembelajaran kenormalan baru diantaranya menjelaskan senin-rabu kegiatan tatap muka antara guru dan siswa dengan aplikasi misalnya zoom (sinkronus).

Pendidikan maupun pembelajaran harus tetap bisa berjalan. Adanya covid-19 ini tidak serta merta membuat semuanya serba off, tapi ini adalah tantangan dimana yang sudah kreatif dituntut untuk inovatif. Implementasi pembelajaran yang akan digunakan untuk ajaran baru 2020/2021. Tantangan saat ini yaitu bagaimana agar pembelajaran daring bisa memiliki ketercapaian atau bisa mencapai kompetensi KI, KD dan pembelajaran yang tidak berbeda secara signifikan dengan pembelajaran tatap muka atau bahkan lebih baik dari pembelajaran tatap muka. Dengan adanya pandemi ini membuat pemerintah dan sekolah untuk menemukan cara yang tetap dapat mengefektifkan pembelajaran kepada peserta didik. Kegiatan pembelajaran yang hakikatnya harus dilakukan dengan interaksi antara pendidik dan peserta didiknya secara langsung tidak diizinkan untuk dilakukan. Tetapi, disini lain pemberian pembelajaran pada peserta didik harus tetap dilakukan walaupun tanpa adanya interaksi atau kontak langsung dengan para peserta didik.

Kepala sekolah memegang perang penting untuk memberikan pembimbingan atau pengarahan serta pengawasan kepada tenaga pendidik dalam pelaksanaan pembelajaran di tengah pandemi. Kepala sekolah dituntut untuk dapat memahami kebijakan pemerintah mengenai prosedur yang harus dipenuhi dalam masa pandemi. Kepala sekolah harus berupaya untuk mengonfigurasikan kebijakan pemerintah agar dapat disesuaikan dengan kemampuan serta kondisi sekolah, peserta didik, tenaga pendidik, dan seluruh warga sekolah lainnya.

\section{Kurikulum K - 13 Sebelum Pandemi Covid - 19}

Kurikulum 2013 yaitu kurikulum yang terpadu sebagai sebuah konsep yang dapat dikatakan sebagai sebuah sistem dan pendekatan pembelajaran yang melibatkan beberapa disiplin ilmu atau mata pelajaran untuk memberikan pengalaman bermakna dan luas kepada peserta didik. Konsep Kurikulum dapat dikatakan bermakna jika peserta didik dapat memahami konsep yang mereka pelajari secara realitis. ${ }^{18}$ Kurikulum 2013 disiapkan untuk mencetak generasi yang siap dalam menghadapi tantangan masa depan, maka dari itu kurikulum disusun untuk mengantisipasi perkembangan masa depan. ${ }^{19}$

${ }^{18}$ Sofan Amri, Panduan Memahami Kurikulum 2013, (Jakarta : PT Prestasi Pustakarya, 2013), hlm 29

19 ibid... hlm 28 
Leadership: Jurnal mahasiswa manajemen pendidikan Islam

ISSN (P): 2721-7108, ISSN (E): 2715-0399

Vol. 03 No. 01 bulan Desember 2021

Tujuan kurikulum mencakup empat kompetensi, yaitu :

1. Kompetensi Sikap Spiritual.

Menerima dan menjalankan ajaran agama yang dianutnya

2. Sikap Sosial, Menunjukkan perilaku jujur, disiplin, tanggung jawab, santun, peduli, dan percaya diri dalam berinteraksi dengan keluarga, teman, guru, dan tetangganya

3. Pengetahuan.

keteladanan, pembiasaan, dan budaya sekolah dengan memperhatikan karakteristik mata pelajaran serta kebutuhan dan kondisi peserta didik.

4. Keterampilan.

Kompetensi tersebut dicapai melalui proses pembelajaran intrakurikuler, kokurikuler, dan/atau ekstrakurikuler. Rumusan Kompetensi Sikap Spiritual, yaitu "Menerima dan menjalankan ajaran agama yang dianutnya". Adapun rumusan Kompetensi Sikap Sosial, yaitu Kedua kompetensi tersebut dicapai melalui pembelajaran tidak langsung (indirect teaching).

\section{PENUTUP}

Pada era Covid-19 ini merupakan sesuatu yang belum pernah di hadapi oleh masyarakat. Segala bentuk pembatasan serta ketentuan yang ditentukan pasti akan menimbulkan banyak pertanyaan dan juga membutuhkan waktu beradaptasi dengan perubahan tersebut. Berbagai hal baru bermunculan menuntut masyarakat dalam berbagai bidang pula untuk dapat mengadaptasi ketentuan yang ada. Terutama dalam paparan ini, mengenai dampak Covid-19 di bidang pendidikan. Berdasarkan paparan tersebut didapatkan bahwa dampak yang paling terasa dengan adanya pandemi Covid-19 di Sekolah Dasar Islam Mohammad Hatta.

Kurikulum SDI Mohammad Hatta ini diperuntukan kepada semua warga sekolah ,terutama peserta didik, pendidik dan tenaga kependidikan, pembentukan budaya sekolah dapat dilakukan oleh sekolah melalui serangkaian kegiatan perencanaan, pelaksanaan pembelajaran yang lebih berorientasi pada peserta didik, penilaian bersifat komprehensif perencanaan tingkat sekolah pada intinya adalah melakukan penguatan dalam penyusunan di tingkat SDI Mohammad Hatta, seperti menetapkan Visi, Misi, tujuan, Struktur kurikulum, Kalender akademi dan penyusunan silabus. keseluruhan perencanaan sekolah yang bertitik tolak dari melakukanan alisis kekuatan dan kebutuhan sekolah akan dapat dihasilkan progam pendidikan yang lebih terarah yang tidak semata - mata berupa penguatan ranah pengetahuan dan ketrampilan melainkan juga sikap perilaku yang akhirnya dapat membentuk ahklak yang baik, Pendidikan budaya dan karakter bangsa bukan merupakan matapelajaran yang berdiri sendiri atau nilai yang diharapkan, tetapi lebih dari upaya penanaman nilai - nilai baik melalui matapelajaran, progam pengembangan diri maupun budaya sekolah.

Peta nilai yang dapat diajarkan melalui berbagai mata pelajaran sesuai denganKompetensi Inti ( KI ) dan Kompetensi Dasar ( KD ) yang terdapat dalam Standar Isi ( SI ) begitu pula melalui pengembangan diri, seperti kegiatan rutin sekolah, kegiatan spontan, keteladanan, perencanaan pengembangan pendidikan budaya dan karakter bangsa ini dilakukan oleh semua pemangku kepentingan di sekolah yang secarabersama-sama sebagai 
Leadership: Jurnal mahasiswa manajemen pendidikan Islam

ISSN (P): 2721-7108, ISSN (E): 2715-0399

Vol. 03 No. 01 bulan Desember 2021

suatu komunitas pendidik diterapkan dalam kurikulum sekolah yang selanjutnya diharapkan menjadi budaya sekolah. Pada pelaksanaan Kurikulum 2013 di tingkat sekolah pada tahun pertama, program evaluasi dan refleksi penerapan Kurikulum 2013 tetap di laksanakan dengan harapan dapat melakuka perbaikan dan penyempurnaan kurikulum yang telah berjalan dan yang akan dilaksanakan.

\section{Daftar Pustaka}

Abuddin, Nata, , 2003. Manajemen Pendidikan. Jakarta: Prenada Media.

Amanah,Dita. 2010 Pengantar Manajemen. Medan: UNIMED.

Amri, Sofan, 2013. Panduan Memahami Kurikulum 2013, Jakarta : PT Prestasi Pustakarya.

Asrohah, Hanun. 2015. Pengembangan Kurikulum, Cet. VII : Surabaya : Kompertais IV Press.

Cunningham, Willian, G, 1982. Systematic Planning for Educational Change, First Edition, Mayfield Publishing Company, California.

Hamalik, Oemar, 2013. Dasar-Dasar Pengembangan Kurikulum. Cet. V ; Bandung : PT Remaja Rosdakarya.

Hasan, S. Hamid. 2009. Evaluasi Kurikulum. Cet. II; Bandung : PT Remaja Rosda Karya.

Herujito, Yayat M., 2006 Dasar-Dasar Manajemen. Jakarta: PT Grasindo.

Merrill, M.D., 1938. Component Display Theory, dalam C.M. Reigeluth (Ed.) Instructional Design Theories and Modelas: An Overvieew Of their Current Status. Hillsdale, N.J., Lawrence Erlbaum Associates.

M, Jasa Ungguh, 2014. Metodologi Penelitian Pendidikan. Yogyakarta: Gava Media.

Moloeng, Lexi J 2006. Metodologi Penelitian Kualitatif, Bandung : Remaja Rosdakarya.

Mulyasa, E. 2009. Implementasi Kurikulum Tingkat Satuan Pendidikan Kemandirian Guru dan kepala Sekolah,. Jakarta : Bumi Aksara.

Nita, 2014. Manajemen Kurikulum. Bandung : Perdana Publishing.

Suharsimi Arikunto, 1998. Prosedur Penelitian; Suatu Pendekatan Praktek, Yogyakarta : PT. Rineka Cipta. 